\title{
Effects of Titanium Carbide and E-Glass on the Mechanical Properties of Aluminum 7075 Metal Matrix Composites
}

Vijetha Vardhan $\mathrm{R} \mathrm{N}^{1}$ and Dr.Girisha $\mathrm{H} \mathrm{N}^{1}$

${ }^{1}$ Affiliation not available

September 29, 2021

\section{Hosted file}

3rd Journal Paper_Vijetha.pdf available at https://authorea.com/users/438428/articles/539629effects-of-titanium-carbide-and-e-glass-on-the-mechanical-properties-of-aluminum-7075metal-matrix-composites 